University of Wollongong

Research Online

Faculty of Social Sciences - Papers (Archive) Faculty of Arts, Social Sciences \& Humanities

$1-1-2018$

Property speculation, global capital, urban planning and financialisation: Sydney Boom, Sydney Bust redux

\author{
Alistair Sisson \\ University of Sydney \\ Dallas Rogers \\ University of Sydney \\ Christopher R. Gibson \\ University of Wollongong, cgibson@uow.edu.au
}

Follow this and additional works at: https://ro.uow.edu.au/sspapers

Part of the Education Commons, and the Social and Behavioral Sciences Commons

Research Online is the open access institutional repository for the University of Wollongong. For further information contact the UOW Library: research-pubs@uow.edu.au 


\title{
Property speculation, global capital, urban planning and financialisation: Sydney Boom, Sydney Bust redux
}

\author{
Abstract \\ In this 'Thinking Space' essay we revisit Maurie Daly's 1982 book Sydney Boom, Sydney Bust, fuelled by \\ concern for how Australian cities are being transformed by financialised real estate. Daly's insights \\ remain highly relevant to Sydney and other cities around Australia and the world today. Poorly planned \\ densification, inflated property markets, land speculation, and housing poverty are all outcomes of the \\ (global) capitalist intersection of finance and land in Australia. The overwriting of Aboriginal country with \\ colonial-capitalist systems of land ownership set in train a process of land and housing booms, bubbles \\ and busts that are better understood by their circular continuity rather than as a set of ephemeral \\ ruptures. It is the property and finance system itself, rather than any ruptures to it, that reproduces \\ unequal and alienating social relations. Researchers investigating property speculation, global capital, \\ urban planning and financialisation, we argue, ought to revisit this key text to inform their contemporary \\ analyses. Moreover, those wielding power over Australian urban affairs would do well to read it too, lest \\ its lessons be ignored for another generation.

\section{Disciplines} \\ Education | Social and Behavioral Sciences

\section{Publication Details} \\ Sisson, A., Rogers, D. \& Gibson, C. (2019). Property speculation, global capital, urban planning and \\ financialisation: Sydney Boom, Sydney Bust redux.Australian Geographer, 50 (1), 1-9.
}




\title{
Thinking Space:
}

Property speculation, global capital, urban planning and financialization: Sydney Boom, Sydney Bust Redux

\author{
Alistair Sisson \\ School of Geosciences \\ Rm 478a, Madsen Building (F09) \\ University of Sydney NSW 2006 \\ Email: alistair.sisson@sydney.edu.au \\ Telephone: +61 407738537 \\ Dallas Rogers \\ School of Architecture, Design \& Planning \\ University of Sydney NSW 2006 \\ Email: dallas.rogers@ $@$ sydney.edu.au \\ Telephone: +61 432295605 \\ Chris Gibson \\ School of Geography and Sustainable Communities \\ University of Wollongong \\ Wollongong NSW 2522 \\ Email: cgibson@uow.edu.au \\ Telephone: +61242214261
}




\title{
Thinking Space:
}

Property speculation, global capital, urban planning and financialization: Sydney Boom, Sydney Bust Redux

\begin{abstract}
:
In this Thinking Space essay, we revisit Maurie Daly’s 1982 book, Sydney Boom, Sydney Bust, fuelled by concern for how Australian cities are being transformed by financialised real estate. Daly's insights remain highly relevant to Sydney and other cities around Australia and the world today. Poorly planned densification, inflated property markets, land speculation, and housing poverty are all outcomes of the (global) capitalist intersection of finance and land in Australia. The overwriting of Aboriginal country with colonial-capitalist systems of land ownership set in train a process of land and housing booms, bubbles and busts that are better understood by their circular continuity, rather than as a set of ephemeral ruptures. It is the property and finance system itself, rather than any ruptures to it, that reproduces unequal and alienating social relations. Researchers investigating property speculation, global capital, urban planning and financialization, we argue, ought to revisit this key text to inform their contemporary analyses. Moreover, those wielding power over Australian urban affairs would do well to read it too, lest its lessons be ignored for another generation.
\end{abstract}

Keywords: property, land, housing, finance, financialisation, settler-colonialism 


\section{Introduction}

Australian cities are awash with construction activity. From Collingwood to Kogarah, Marrickville to Newstead, every passing month seems to bring with it a new, sold-off-theplan high-rise apartment tower. Real estate, it seems, is the true national sport. Indeed, Australia now hosts the world's most active market for securitized home loans (Reuters 2017) and has the world's second highest (and rising) levels of household debt (Stewart 2017). There are reportedly more cranes in the east coast capital cities than in the entire continent of North America (Letts 2016). And with the cranes and high-rise towers, come social problems and no respite from affordability crises: overcrowded schools, longer working hours to pay off mortgages, worsening homelessness. It is perhaps no surprise, then, that in recent polls (Nicholls 2017), densification and housing affordability are among the issues of most concern to Australian voters.

Yet debates about land and housing crisis in Australia are nothing new (Dufty-Jones 2018). Indeed, the languages that have formulated around land and housing booms and busts over the last 200-odd years are fabulously revealing. One of the first examples of an anti-land speculation measure appeared in 1812, when Governor Macquarie inserted a clause into each colonial land grant that forbade the resale of the granted land for a period of five years. Macquarie 'had found as very prevalent practice "the obtaining grants for the sole purpose of selling them"' (Roberts 1924, 21, citing Macquarie). Toward the end of the century, in 1889, Harold Sparks was reported in a Sydney newspaper to be 'A Victim of the Land Boom... The cause of insolvency is given as land speculation' (Evening News 1889, 5). By the turn of the century, in 1898, George Sutherland was waxing lyrical in a book chapter titled 'Land Booms' under the subtitle 'City Investments': 
City land booms have always been a snare of the people of the Australian colonies. Sydney, Melbourne, and Adelaide have been each in its turn badly smitten by the mania for gambling building allotments... But the memories of commercial disaster soon wear off, and when another spell of buoyant, confident, hopefulness and extravagance takes possession of the community, the same wild speculation and the same inevitable collapse of credit ensure... These booms were only repetitions, on a larger scale, of what had already taken place repeatedly from the very earliest colonial days. In 1842, both in Sydney and Melbourne, business was so brisk and town properties passed from hand to hand so rapidly that almost everyone seemed to be making a fortune. (Sutherland 1898, 211-2).

Concerned with present day real estate speculation and its impacts in Australian cities, but also seeking to understand continuities with the past, in this Thinking Space essay we revisit the Australian geographer Maurie Daly’s 1982 classic, Sydney Boom, Sydney Bust: The City and Its Property Market, 1850-1981 (Daly 1982). Revisiting Daly's book at this point in Australia's land and housing history seems timely, for two reasons. First, we seek to illuminate Daly's ideas and show their continued relevance. The discipline of geography with its focus on spatiality and temporality, time and space, process and events - has always been well placed to critically intervene into public debates that have a long and sometimes obscure spatiotemporal tail, such as land and housing booms and busts. Indeed, the key analytical tools of spatiality and temporality allow geographers to separate out a longue durée of continuity from the rupture of an isolated event. Daly documents how land and housing booms, bubbles and busts have been continually creating and destroying the fortunes of the colonisers since soon after the founding of the colony. The overwriting of Aboriginal peoples' land management practices with white colonial systems of land management did not result in a financially stable system of land and housing management. Rather it set in train a 
process of land and housing booms, bubbles and busts that are better understood by their circular continuity than as a set of ephemeral ruptures that this temporal language seems to suggest. This is the central analytical point of Sydney Boom, Sydney Bust.

Second, we want to retrieve from Sydney Boom, Sydney Bust insights that will benefit contemporary scholarship. A book in many ways decades ahead of its time, Sydney Boom, Sydney Bust anticipated the recent explosion of academic work on financialisation, globalisation and real estate (cf. Christophers 2015), as well as a growing contemporary literature critical of the function of urban planning practice engulfed by neoliberal ideologies (e.g. Schatz and Rogers 2016; Greco 2018; Inch 2018). Urban planning has manifested as a tool for guiding and driving property development when it should be used as a mechanism for creating a more just or socially equitable city. We then reflect on what Daly brought to light and what he left in the dark with his analysis (notably, critique of the colonial dispossession of Aboriginal land), with future prospects for critical research on urban property markets in mind.

\section{Centring global capital in land and housing markets}

At the heart of Sydney Boom, Sydney Bust is the fortification of global capital, particularly within the financial service sector, through urban property and infrastructure development. It is a scholarly theme Daly returned to throughout his career (see, for example, Daly et al. (1996) and Stimson et al. (1998) on the role of foreign investment in Australian cities in the 1990s). Global capital also has a longer history in Australia in relation to land than is generally understood. In 1804, Governor King lamented that the over-production of agricultural produce in the colony was just as difficult to manage as under-production, and 'in the last few years of King's rule, the Isle of France, Tahiti and the outlying settlements were 
all considered as possible markets' (Roberts 1924, 15). Thus, agricultural production ${ }^{1}$, as a modality for extracting wealth from the land, was linked soon after the colony's inception (at least in the mind of Governor King) to the colonial global economy. It has been a central motif of Australian land politics ever since. Daly takes up the connection between local land and global capital markets in earnest from the 1850s, but engages substantially with this idea from the mid $-20^{\text {th }}$ century. Without using the term, Daly's account pre-empts the contemporary scholarship on the financialization of housing and urban development. He suggests that the responsibility for the boom lay more with the financiers than with the property developers who were (and perhaps still are) often called to account in the public debate about housing affordability. The built environment is essential to creating and storing surplus value, and it continues to be heavily influenced by finance capital (cf. Aalbers 2017; Murphy 2017). To a considerable extent, financial controls, algorithms and funding products determine what gets built and where.

The mining boom of the mid- to late-1960s, Daly writes, 'expanded [the] profile of Australia within the international business community' $(1982,4)$. Mining's investment costs - another modality for extracting wealth from the land - was thought to be beyond the capacity of Australia's 'fairly primitive' capital markets $(1982,4)$. Foreign banks and finance companies emerged in the capital vacuum, and began funding mining developments in Australia. With access to the growing Eurodollar ${ }^{2}$ market, Daly argues that the Australian banks and bankers were captivated by the syndication of foreign banks, which were 'often drawn from several countries', and the 'increasing scale and increasing sophistication' this allowed for financing large projects $(1982,4)$. As foreign capital flowed into Australia, Australia’s capital markets

\footnotetext{
${ }^{1}$ In the early days of the colony, food production was low and land grants we issued to allow for increased agricultural production, one aim of which was to secure the colony's food security.

${ }_{2}^{2}$ The term Eurodollar refers to United States dollar-denominated deposits held in banks outside of the United States and which, therefore, escape the Federal Reserve Board regulation.
} 
were further enmeshed within the international system, deepening the nation's embeddedness in the global economy. Sydney, where the banks and finance companies were typically headquartered, became an important node in a network of international financial centres (O’Neill et al. 2018). The city's economy and built environment were transformed as manufacturing and retailing struggled and the financial sector expanded, particularly in the CBD. Office towers and high-rise apartments proliferated, and real estate became a third modality for extracting wealth from the land with global finance.

With the 'mining boom' fading in the latter part of the 1960s (a recurring narrative in the Australian minerals sector) and contraction in the manufacturing sector, 'too much money was chasing too few investment opportunities' (Daly 1982, 62). Property was one of few avenues to which syndicated global capital seeking a local investment could 'switch' (Harvey 1978). The property boom began with commercial real estate in the CBD in the mid-1960s, before filtering through commercial and residential real estate throughout the city later in the decade. The financiers did not simply facilitate other firms' growth but grew substantially in their own right, further fuelling the boom that they were financing (cf. Engelen 2003). By the early 1970s, and with the help of the property market, 'finance houses had moved from relative obscurity to hold over $26 \%$ of the Australian credit market with an estimated value of $\$ 17000$ million per year' (Daly 1982, 98).

The supposed security of real estate investment led to the over-production of commercial real estate, largely in the form of office space, which in turn suppressed rents. Increasing construction costs - in part due to the social movements upon which Daly scarcely dwells (cf. Burgmann \& Burgmann 1998) - led to a diversification of investment, and commercial real estate activity was pushed into the residential sector. Daly argues that the transition from 
commercial to residential real estate investment both diversified the real estate actors and help to produce the mum-and-dad real estate investor:

[T]he finance companies lent to a vast range of people, and were ultimately responsible for the acceleration in the rate of inflation of land values in Sydney in the early 1970s. [They] provided most of the funds which enabled property developers to assume high gearing ratios and to compete outlandishly with each other for land parcels. Soaring prices brought rising profits and large turnovers for both financiers and developers, and bred a sublime optimism which allowed even higher gearing ratios and more unstable financial arrangements. The jangle of profits brought more peripheral groups into the development field with estate agents and solicitors, the middlemen of the industry, leading the way. The semi-professionals were followed by the rich amateurs: doctors, dentists and businessmen eager for a share of the profits. The rich were succeeded by the would-be rich, the confidence men and the gullible, whose backgrounds varied from farmers, to teachers, to tea-ladies, to gamblers, but who were united in their determination to reap the rewards offered by property. The finance companies funded them all. $(1982,71-2)$

Sources of foreign capital also evolved as the 'boom' mutated into residential construction. British firms had historically been the predominant sources of foreign capital and they were at the forefront of the initial period of investment in commercial office-space construction. But Asian firms and investors gradually became more prevalent as more, and increasingly risky, sites became available (Daly 1982, 69); this heightened the cultural politics of foreign capital and unsettled the white colonial power base (Rogers 2017; O’Neill et al. 2018), a point which we return to below. 
With financialization, the "risks that were once limited to a specific actor in the productionconsumption chain become risks for all of the actors involved in a specific industry" (Aalbers 2008, 150). Such was the case with Sydney's subsequent property 'bust': Daly writes that "between 20 and 30 per cent of the investment in finance companies were made by public companies, institutions and superannuation funds; the remainder was subscribed by the general public. [...] The victims of the corporate failures therefore included tens of thousands of ordinary people, and in a number of cases life savings were wiped out" $(1982,104)$. As Daly shows, the risks associated with welding the city's fortunes to property speculation are borne unevenly, and often in less than transparent ways.

\section{Planning the boom}

Urban Planning is often presented as a bulwark against rapacious urban development. In terms of housing, 'better planning' should prevent the construction of (too many) unaffordable, low-amenity and inaccessible dwellings. Daly exposed the urban planning system as a policy toolkit that has been captured by developers and recalibrated to drive the commodification of land through subdivision and speculation - an insight that remains evertrue today. This is a radical departure from seeking to use the planning system to provide housing that might lead to a more equitable city. Daly showed how urban planning was enrolled into the service of private property and subsequently pushed housing, via rezoning and subdivision, toward the city's fringe.

Thus, 'urban renewal' led to speculative developers placing more housing commodities into the housing system than the system could deal with, and a land and property boom quickly shifted course towards a bust. Urban planners scrambled to manage the consequences of the speculative development by providing, for example, public housing in sites that were 'left 
over', or by reclaiming the sites of failed projects. In Woolloomooloo, as Daly recounts, a suite of commercial construction projects was proposed to provide office space for 90,000 workers, but failed in the face of opposition from organised labour and residents. The NSW Housing Commission stepped in to purchase the land but were forced, following a High Court decision, to pay $125 \%$ of their initial offer because the area had been rezoned to the highest density zoning $(1982,67)$. In terms of strategic planning, the 1968 Sydney Region Outline Plan outlined a growth corridor strategy for the city and was dubbed 'the punters guide' by developers and speculators; any uncertainty about where to buy and when was clarified therein $(1982,10)$. Even seemingly benign activities such as the provision of new water infrastructure was read like a map to a 'speculators paradise' $(1982,118)$.

The historical expansion of Sydney's railway network is emblematic of this contradiction within urban planning. The expansion of the railway networks in the $19^{\text {th }}$ and early $20^{\text {th }}$ centuries produced new wealth for those living along the rail network and the developers that sought them out. The new railway and tram services to Hurstville (1884), between Hornsby and St Leonards (1890; later to Milsons Point), from Ashfield to Belmore (1895), as well as to Mosman (1897), Chatswood (1908), and Lane Cove (1909) were accompanied by land rezoning and subdivision, speculative land purchases, and a rapid increase in land prices. In 1905, Daly writes, the average price of land in the Belmore-Bankstown area was $£ 111$ per hectare; with the extension of the railway from Belmore to Bankstown in 1909, this rose to $£ 370$ in 1910 and $£ 421$ in $1913(1982,162)$. While the expansion of public transportation produced social benefits it simultaneously produced social disadvantage through the drastic increase in land values, which were captured by a few land holders and then developers. Daly discusses the 'Sydney Region Outline Plan and the betterment tax' $(1982,10)$, a precursor to the contemporary discussions about 'value capture' on land value increases that result from 
transit-oriented development (cf. Jones and Ley 2016). Urban planning fuelled rather than slowed speculative development, with planning documents and plans signalling to the developers where they should purchase land and anticipate a windfall. Contemporary parallels include the recent strategic planning of 'growth centres', 'priority precincts' and 'growth corridors', and attempts to harness 'value uplift' on public land to finance public transport infrastructure in Parramatta and along the Bankstown train line in Sydney. Current land-banking, unsolicited proposals that pre-empt rezonings, and aggressive land assembly tactics in individual suburban streets (sometimes bordering on bullying) are the latest iterations of the same process.

\section{Daly Redux: Settler-colonialism, the context of all contexts}

The colonisation of Australia is not an historical event of the past but an ongoing process that merely began with the arrival of the first fleet in 1788 (Porter 2018). A 'new policy of 1804 meant a rational and progressive control of land policy, allowance for the first time being made by expansion. The Government desired to group settlers in "townships" or shires of up to 30,000 acres with farms radiating round centrally placed "towns" (Roberts 1929, 15). The colonial frontier pushed across the continent over half a century; a slow and often violent metaphorical line that would eventually dispossess Aboriginal peoples of their land. In the end, writes Henry Reynolds $(2013,248)$, the 'settlers were engaged in the forcible transfer of the most productive land rights across the continent... It, too, was a transaction of global significance involving the seizure of control of one of the world's greatest land masses'. Daly's analysis indirectly connects to this debate from the 1850 s by exposing the predominance and influence of British foreign capital until the latter stages of the boom of the 1960s and 1970s. For example, in the first half of the 1880s, Australia received 40 percent more funds from the United Kingdom than were received by the United States and 77 percent 
more than Canada $(1982,154)$. British investment rose by 54 percent in the second half of the decade. Daly writes that the Sydney of the early 1880s was a 'paradise for speculators', where 'money was plentiful, because it could be employed at twice the prevailing British rates of 3.5 to 5.0 percent' and where demand could be stimulated by substantial immigration (1982, 158). British capital and bodies - and those of other territories of the British empire were central not only during the early decades of the establishment of the Australian colonies, they were central to its maintenance and development over the next 200 years (Rogers 2017). The global movement of foreign white bodies and financial capital comprise some of the fundamental components for building the 'property-owning democracy' within these settlersocieties, where it became 'the duty of every [white] man to have a home of his own. The home is the foundation of the nation' (Phillips and Co. 1886, in Daly 1982, 132, original emphasis). This remains a powerful discourse today. But within this analysis Daly exposes the centring of the urban in the land claiming process; as the purchase of land was financed by city-based banks, the receipts from these purchases were redirected back to the cities and deposited in urban financial institutions. Thus, the control of agricultural lands was gradually transferred to city-based interests, which spurred on and financially underwrote urban development (1982, 153-4).

What is striking about Daly's analysis, then, is that despite looking toward early Australian history to understand the origins of a property system that is marked by booms and busts, Daly largely overlooks the foundational point that settler-colonialism is the context of all contexts when it to comes to land and housing in Australia. Ultimately, Daly locates the causes of booms and busts in 'the extreme openness of Australia to the world capitalist economy and the demands for capital, labour and trade associated with this, and the inherent jerkiness of the capitalist mode of growth' $(1982,150)$. With the benefit of settler-colonial 
hindsight this is a wholly unsatisfactory colonialist diagnosis, which belies the more instructive analytical and political lessons that can be gained from a critical (re)reading of this book today.

\section{History invariably repeats: boom and bust ad infinitum?}

Read alongside subsequent critiques of settler-colonial land and housing (Porter 2018), Daly's book still provides a compelling rebuttal to the presentist narrative that represents booms and busts as ephemeral and historically exceptional ruptures within an otherwise stable system of land and housing. He shows that it is this system itself, rather than any ruptures to it, that reproduces unequal and alienating social relations (cf. Madden $\&$ Marcuse 2016). And thus, Daly concludes his chapter on subdivision and speculation with a diagnosis of the city that this system (re)produces. It is a diagnosis that will no doubt resonate with contemporary readers:

At the end of it all the city had sprawled even further; services were even more inadequate; the young and the poor were relatively worse off; investment funds which might have been put into production or socially useful activities had been dissipated; and millions of dollars of small investors' funds had been lost as sharks and charlatans grew rich. $(1982,131)$

Other echoes of Sydney Boom, Sydney Bust continue to reverberate around Australia and the world. Two years ago, Singaporean developer Koh Wee Seng had within twelve months successfully sold 98 percent of the 1103 off-the-plan apartments in his proposed 101-storey Tower 108 in Melbourne. Now, as this Thinking Space essay was poised to go to print, news reports emerged of Koh Wee Seng's brother, Koh Wee Meng (famed for building budget hotels in Singapore's red-light Geyland district), struggling to find off-the-plan buyers for his 
78-storey 'Beyoncé' tower (so nick-named because of its curvy design) slated for a site not far across the Yarra from Tower 108 (Lenaghan 2018). Chinese investors are pulling out of capital city markets, due in part to tighter lending restrictions in Australia and in China (Stewart 2018). In Sydney, new real estate project launches halved in 2017 (Schlesinger 2018). Furthermore, in Brisbane, some 52 projects totalling an estimated 10,000 apartments were abandoned or deferred in the 2017-2018 period (Tilley 2018). How this will inform the cultural politics about foreign real estate investment is unknown. What we do know is that over 60 per cent of Sydneysiders do not want more individual foreign investment in residential real estate in Sydney. But those who are financially invested in the property market are more likely to be supportive of foreign investment than those who are not invested in the property market (Rogers et al. 2018).

For years, densification has proceeded on the basis of arguments put forward by property industry lobbyists about under-supply and affordability. This latest cycle of boom, bubble and bust reveals the fallacy of such arguments (Gurran et al. 2018). Even if population growth continues apace, when risk of failure to deliver surpluses on investment mounts, developers and financiers will actively retreat from the market. And if Daly's argument holds true (and we believe it does), after the bust our cities will be left dealing with badly planned precincts, a continued under-supply of affordable housing, toxic cultural politics around white/colonial versus Asian global capital, and unresolved pressures on social infrastructure. Notwithstanding its settler-colonial overtones, Sydney Boom, Sydney Bust remains a valuable, integrative analysis of how finance, land and capital reshape our cities - for the worse. Researchers of financialisation and its impacts ought to revisit this key text to inform their own contemporary analyses. Those wielding power over Australian urban affairs would do 
well to read it too, lest the lessons from Sydney Boom, Sydney Bust be ignored for another generation. 


\section{References}

Aalbers, M. B. 2017. "The Variegated Financialization of Housing." International Journal of Urban and Regional Research 41: 542-554.

Aalbers, M. B. 2008. "The Financialization of Home and the Mortgage Market Crisis." Competition \& Change 12: 148-166.

Christophers, B. 2015. "The limits to financialization." Dialogues in Human Geography 5: 183-200.

Daly, M. T. 1982. Sydney Boom, Sydney Bust: the City and its Property Market, 1850-1981. Sydney \& Boston: G. Allen \& Unwin.

Daly, M., Stimson, R., and Jenkins, O. 1996. "Tourism and Foreign Investment in Australia: Trends, Prospects and Policy Implications." Australian Geographical Studies 34: 169184.

Dufty-Jones, R. 2018. "A historical geography of housing crisis in Australia." Australian Geographer 49: 5-23.

Engelen, E. 2003. "The Logic of Funding European Pension Restructuring and the Dangers of Financialisation." Environment and Planning A 35: 1357-1372.

Evening News. 1889. A Victim of the Land Boom. Sydney, NSW: Sat 31 Aug 1889: 5.

Greco, E. 2018. "Questioning the vertical urbanization of post-industrial cities: the cases of Turin and Lyon." Built Environment 43: 555-570.

Gurran, N., Randolph, B., Phibbs, P., Ong, R. and Rowley, S. 2018. "Affordable housing policy failure still being fuelled by flawed analysis." The Conversation, March 14, https://theconversation.com/affordable-housing-policy-failure-still-being-fuelled-byflawed-analysis-92993 (accessed 5 April 2018).

Inch, A. 2018. "'Open for business'? Neoliberalism and the cultural politics of modernising planning in Scotland." Urban Studies 55:1076-1092.

Jones, C. E. and Ley, D. 2016. "Transit-oriented development and gentrification along Metro Vancouver's low-income SkyTrain corridor." The Canadian Geographer 60: 9-22.

Lenaghan, N. 2018. "Unsold Melbourne apartments make no sense for developer Fragrance." Australian Financial Review, 4 April http://www.afr.com/real-estate/unsoldmelbourne-apartments-make-no-sense-for-developer-fragrance-20180320-h0xr0u (accessed 6 April 2018).

Letts, S. 2016. "Apartment glut warning: More cranes on Australian east coast than in North America." ABC News, 20 October http://www.abc.net.au/news/2016-10-21/realestate-warning-more-cranes-in-australia-than-us/7954108 (accessed 5 April 2018).

Madden, D. J., \& Marcuse, P. 2016. In Defense of Housing: the Politics of Crisis. London \& New York: Verso.

Murphy, L. 2017. "Land costs and affordability." Build 163: 59-60.

Nicholls, S. 2017. "Sydneysiders in revolt over development as two-thirds declare the city is 'full'." Sydney Morning Herald 9 October, https://www.smh.com.au/business/companies/sydneysiders-in-revolt-overdevelopment-as-two-thirds-declare-the-city-is-full-20171008-gywl1c.html

O’Neill, P., Knight, E., and Wójcik, D. 2018. “Australia's shifting global engagement: the stuttering rise of financial services and city-based competitiveness." Australian Geographer.

Porter, L. 2018. "From an urban country to urban Country: confronting the cult of denial in Australian cities." Australian Geographer https://doi.org/10.1080/00049182.2018.1456301

Reuters. 2017. "Rush of Australian securitized home loans tempts yield-starved Japanese." May 23 https://www.reuters.com/article/us-australia-securitisation/rush-of-australian- 
securitized-home-loans-tempts-yield-starved-japanese-idUSKBN18J0JX (accessed 5 April 2018)

Rogers, D. 2017. The Geopolitics of Real Estate: Reconfiguring Property, Capital and Rights. London \& New York: Rowman \& Littlefield.

Rogers, D., Nelson, J. and Wong, A. 2018. "Geographies of hyper-commodified housing: foreign capital, market activity and housing stress." Geographical Research (early view)

Roberts, S. 1924. History of Australian Land Settlement (1788-1920). Melbourne: MacMillan.

Schatz, L. and Rogers, D. 2016. "Participatory, technocratic and neoliberal planning: an untenable planning governance ménage à trois." Australian Planner 53, 37-45.

Schlesinger, L. 2018. "Apartment sales, project launches plummet in 2017 as market selfregulates." Australian Financial Review, 27 March http://www.afr.com/realestate/residential/apartment-sales-and-project-launches-plummet-as-marketselfregulates-20180326-h0y079

Stewart, E. 2017. "Chinese investors pull out of Melbourne apartment market." ABC News 24 May. http://www.abc.net.au/news/2017-05-25/chinese-investors-pull-out-ofmelbourne-apartment-market/8557182

Stimson, R. J., Jenkins, O. H., Roberts, B. H., and Daly, M. T. 1998. The Impact of Daikyo as a Foreign Investor on the Cairns-Far North Queensland Regional Economy. Environment and Planning A 30: 161-179.

Sutherland, G. 1898. The South Australian Company: A Study in Colonisation. London: Longmans, Green \& Co.

Tilley, E. 2018. "Nearly 20pc of Brisbane's apartments empty amid oversupply: BIS Oxford Economics." The Courier Mail, 5 April http://www.news.com.au/finance/realestate/brisbane-qld/nearly-20pc-of-brisbanes-apartments-empty-amid-oversupply-bisoxford-economics/news-story/5cd9130dd8d3b95eb4a7bab45921470a (accessed 6 April 2018). 